\title{
Notes
}

\section{The First Step to Apostasy? (An Ethiopian Ruler's Missive to the Sultan Baybars Re-interpreted)}

\author{
Serge A. Frantsouzoff \\ Professor, Institute of Oriental Manuscripts, National Research University \\ Higher School of Economics, St. Petersburg State University, St. Petersburg, \\ Russia \\ serge.frantsouzoff@yahoo.fr
}

\begin{abstract}
A majority of the sources on medieval Ethiopia are written in the Gə‘əz language in the "genre" of history. However, some texts written in Arabic remain equally important. Among such texts the missive addressed by a ruler of Ethiopia to the Mamluk Sultan Baybars (known as al-Malik al-Zāahir) in AH 673 / AD 1274-75 is of considerable interest. The Ethiopian ruler can be identified as the founder of the Ethiopian Solomonic dynasty Yəkunno Amlak. The text of this missive survived in three Arabic versions: in the Islamic "encyclopaedias" by al-Nuwayrī and al-Qalqashadī (resp. AH 730 / AD 1330 and AH 814 / $\mathrm{AD}$ 1412) and in the dhayl (continuation) to the Universal history by al-Makīn, compiled by the Coptic author al-Mufaḍal b. Abīll-Faḍāil in AH 759 / AD 1358. All three versions are almost identical, however, the version by al-Nuwayri is the longest one and the closest to the original. The detailed analysis of this version supplied by the full translation into English made for the first time by the present author clearly shows that the person who wrote it was the amir (commander) of the Amhara and not yet the king of Ethiopia. However, he had an intention to become himself with his people a subject of Baybars to obtain help from him against the Zagwe dynasty. As a consequence, the Ethiopian Christians would have been under the Muslim power. However, the Mamluk Sultan was less interested in that affair.
\end{abstract}




\section{Keywords}

Ethiopia - Arabic sources; Ethiopia - dynasties - Zagwe, Solomonids; Yəkunno Amlak - the first King of the Solomonids; Baybars - the Mamluk Sultan; diplomatic correspondence between the Ethiopian kings and the Mamluks

To reconstruct and interpret the events of the Medieval Ethiopian history one has to rely almost exclusively on the local sources written in the Classical Ethiopic (Gə‘วz) language. These sources are mostly represented by the two "genres", i.e. historical works and hagiography. Some rare exceptions are found among the works written in Arabic and Coptic, which belong to the Christian and Islamic traditions. This fact is even more remarkable since the Ethiopian Church for the period of one and a half thousand years did constitute an integral part of the Coptic Church and the Head of Ethiopic Church was appointed by the Coptic Patriarch.

One of the crucial episode of the Middle Ages in Ethiopia, viz. the coup d'État commonly dated from $\mathrm{AD} 1270$, which brought to power the so-called Solomonic dynasty, is poorly reflected in sources, since it took place before the first Ethiopian chronicles and lives of Ethiopian Saints were written. However, three Arabic historical works preserved a text of the missive sent to the Mamluk Sultan Baybars I in AH 673 / AD 1274-75 by a certain ruler of Ethiopia. ${ }^{1}$ This ruler can be identified as Yəkunno Amlak, ${ }^{2}$ who founded (or according to local legendary tradition restored) that dynasty. These Arabic sources are as follows. 1. The Nihāyat al-arab fi funūn al-adab by Shihāb al-Dīn Aḥmad b. 'Abd alWahhāb al-Nuwayrī (AH 677 / AD 1279-AH 733 / AD 1333), ${ }^{3}$ a book on adab,

1 The references to two more sources (Ibn 'Abd al-Ẓāhir, Muhyìid-Dīn, al-Raw d al-zāhir fì sìrat al-Malik al-Ẓāhir, taḥqīq wa-nashr 'Abd al-'Azīz al-Khuwayțir, al-Riyāẹ, s. a., pp. 430-431; Baybars al-Manșūrī, Rukn al-Dīn, Zubdat al-fikra fì ta'rīkh al-hidjra, taḥīq D.S. Richards, Beirut, 1998, p. 144) given on that occasion by J. Loiseau ("The Hați and the Sultan: Letters and Embassies from Abyssinia to the Mamluk Court", in: Mamluk Cairo, a Crossroads for Embassies. Studies on Diplomacy and Diplomatics, ed. Fr. Bauden, M. Dekkiche, Leiden, 2019, p. 643 (pp. 638-657: chapter 2o)) are not relevant for the present study, since they comprise only short reports about that missive rather than versions of its text.

2 This identification is generally recognized by the scholars specialists in Ethiopian studies (Taddesse Tamrat, Church and State in Ethiopia. 1270-1527, Oxford, 1972, pp. 70, 126; D. Nosnitsin, M.-L. Derat, "Yəkunno Amlak", in: Encyclopaedia Aethiopica, vol. 5, ed. A. Bausi in cooperation with S. Uhlig, Wiesbaden, 2014, p. 45 (pp. 43-46)) as well as by Arabists (J. Loiseau, Op. cit., pp. 638-639, 643).

3 al-Nuwayrī, Shihāb al-Dīn Ahmad b. 'Abd al-Wahhāb, Nihāyat al-arabfífunūn al-adab, taḥīq Nadjīb Mușțafâ Fawwāz wa-Ḥikmat Kashlī Fawwāz, 3o-31, Beirut, s. a., pp. 135-136. It should be pointed to the fact that the editors were less accurate by referring to one of the works by al-Maqrīzì (al-Maqrīzī, Taqī al-Dīn Aḥmad b. 'Alī, Kitāb al-Sulūk li-ma'rifat duwal al-mulūk, 
which comprises a lot of information necessary for educating an efficient official. The historical events are mentioned there until the year AH 730 / AD 1330. 2. Al-Nahdj al-sadìd wa'l-durr al-farìd fi-mä ba'da Ta'rïkh Ibn al-Amìd by alMufaddial b. Abỉll-Faḍāill. The title unambiguously shows that the chronicle is in fact a continuation of the universal history by the Coptic historian George al-Makīn. ${ }^{5}$ The last historical events mentioned there are dated from AH 759 / AD 1358. 3. Subḥ al-a'shâ fì șināat al-insh $\bar{a}^{\prime}$ and completed in AH 814 / AD 1412 by Shihāb al-Dīn Abū'l-Abbās Aḥmad b. 'Alī al-Qalqashandī (AH 756 / AD 1355-AH 821 / AD 1418) a legal scholar and secretary in the Mamluk chancery. ${ }^{6}$

At least two authors of the works mentioned above belonged to the civil administration of the Mamluk Sultanate: al-Nuwayrī and al-Qalqashandī. These people most certainly should have had access to state archives. This fact invites a suggestion that they may well have consulted the original of the missive sent to the Mamluk Sultan Baybars I. The version preserved by al-Nuwayri also seems to be the closest to the original. This is the earliest of the three, most complete and preserves some significant details missing elsewhere. For example, it preserved the title of the sender (in Old Amharic): [A]mharāa mäläk, which betrays the Amharic rather than the Arabic word order and means "Emir of the Amhara". ${ }^{7}$

All three versions of the missive are cited in extenso in the table as below. Their comparison makes clear that there is an overlapping between that by al-Nuwayrī and two others. The version by al-Nuwayrī as the most complete

dj. 1, qism 2, nashr Muḥammad Muștafâ Ziyāda, Cairo, 1936, pp. 615-616) many times (alNuwayrī, op. cit., p. 135: notes 2-6, 8-10, p. 136: notes 1-7), since in the actual text of Kitāb al-Sulūk the information about the missive takes only two lines; as to numerous details mentioned in the commentaries, they are taken mostly from two other sources (see note 4 and note 5 to the present article).

4 About him almost nothing is known (J. den Heijer, "al-Mufaḍdal b. Abī'l-Faḍā'il", in: The Encyclopaedia of Islam, new edition, vol. vii, Leiden, 1993, p. 305).

5 Moufazzal ibn Abil-Fazail, "Histoire des sultans mamlouks", texte arabe publié et traduit en français par E. Blochet, fasc. ii, Patrologia Orientalis, 14 (1920), pp. 383-385 (373-672).

6 al-Qalqashandī, Șubḥ al-A'shâ, dj. 8, Cairo, 1915, p. 120.

7 The written sources allow the Gəəəz term mäl'äk to be interpreted as "chief, commander" along with the usual "messenger, angel” (Е.В. Гусарова, “Церковная иерархия в позднесредневековой Эфиопии" [Church Hierarchy in Late Medieval Ethiopia], Vestnik Pravoslavnogo Sviato-Tikhonovskogo gumanitarnogo universiteta, series iii : Philology, 5/40 (2014), p. 25, n. 20 (pp. 22-32)). In this case the Ge'ez mäl'äk can be an equivalent to the Arabic amìr. On the Amhara, who were not merely an ethnic group, but, first of all, a social stratum, see: S. Chernetsov, "On the Problem of Ethnogenesis of the Amhara”, in:Der Sudan in Vergangenheit und Gegenwart (Sudan Past and Present), hrsg. R. Gundlach, M. Kropp, A. Leibundgut, Frankfurt am Main - Berlin - Bern, 1995, pp. 17-35. 


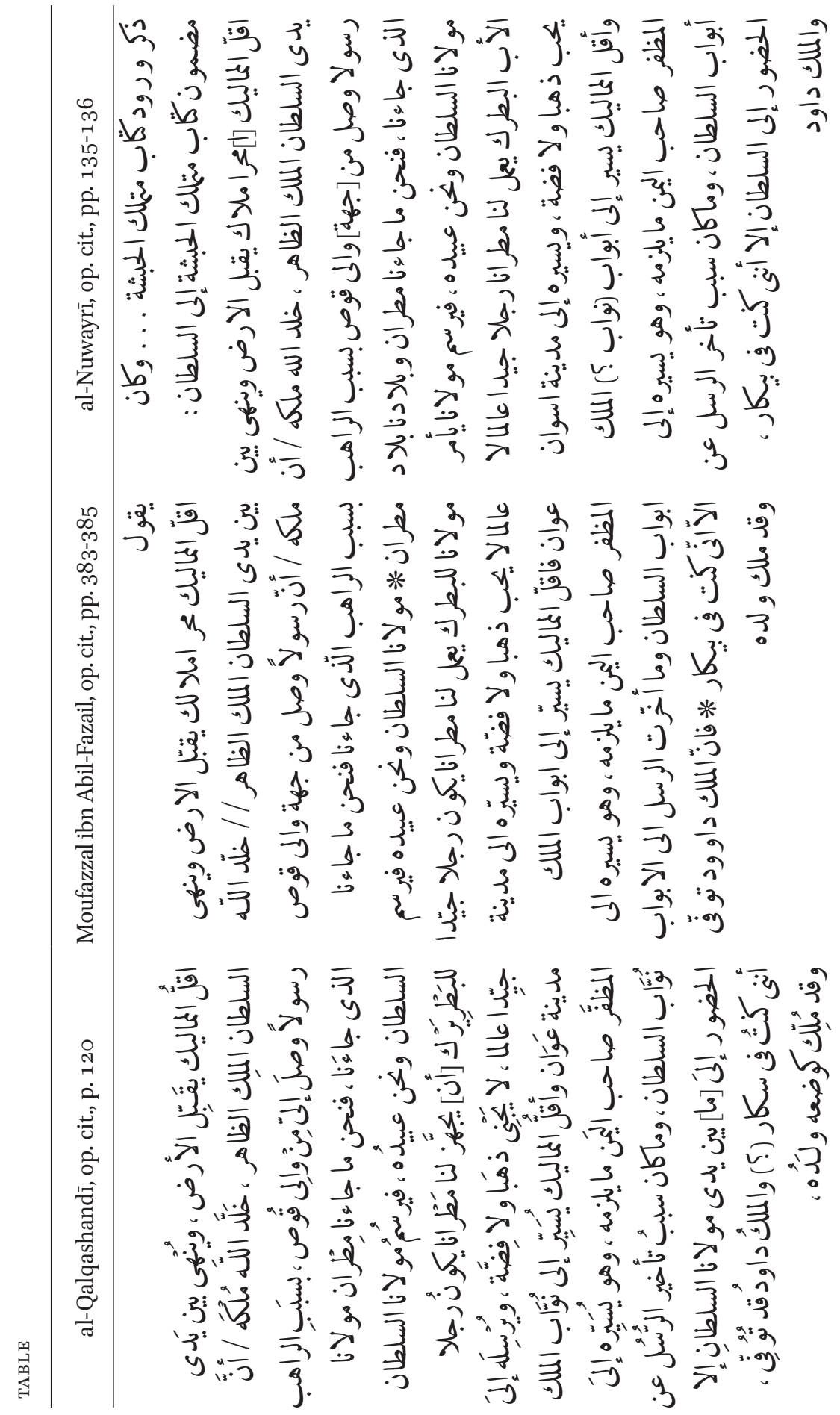




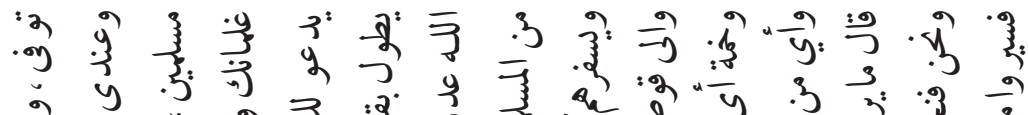

: के

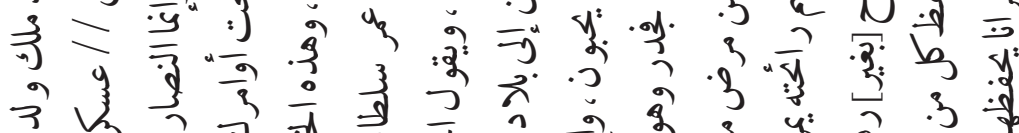

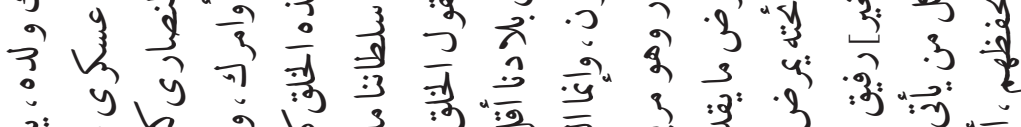

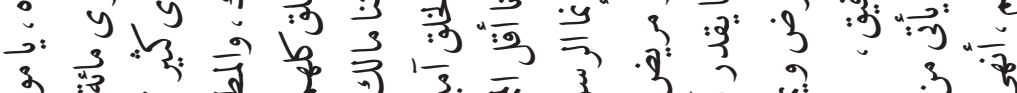

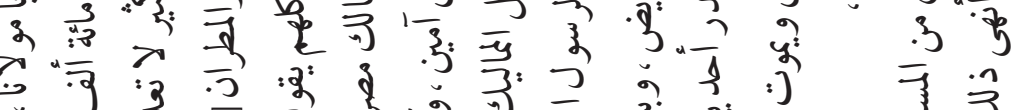

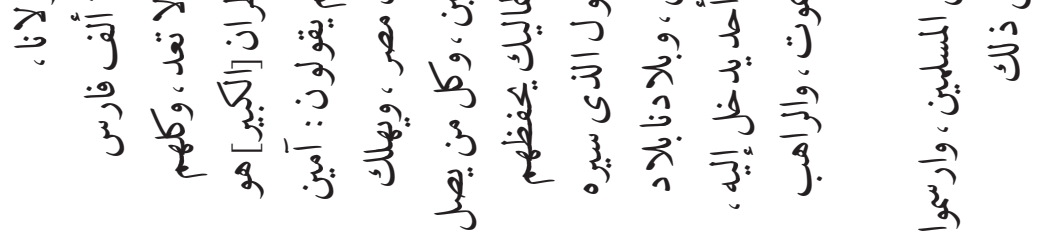

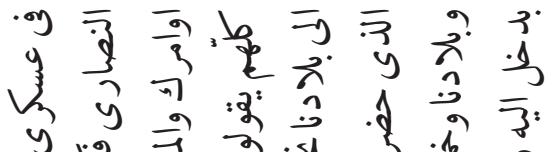

पे है

. 30 ,

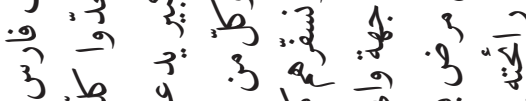

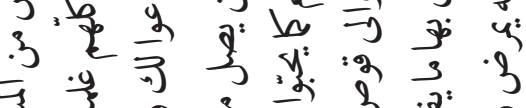

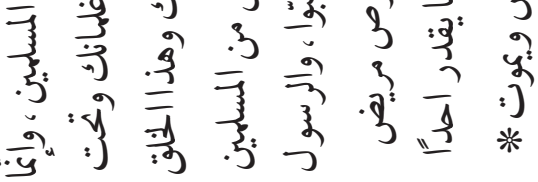

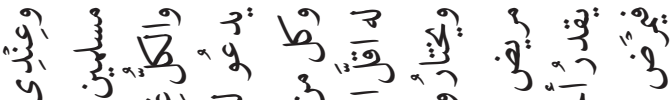

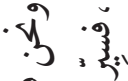

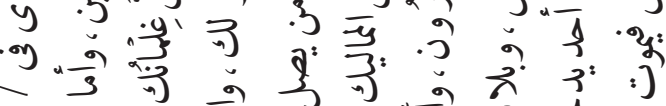

:

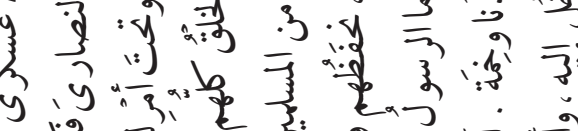

落

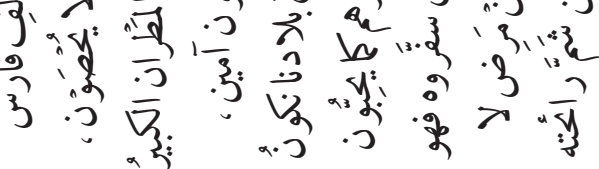

.3

$\frac{\pi}{3}$ 
makes the translation of the versions by al-Mufaḍal b. Abīll-Faḍāil and alQalqashandī redundant. By supplying a translation of the version by al-Nuwayrī one has to mention that this text has already been translated. The full translation from Arabic into Russian has been already offered by M. Tolmacheva in 2002. However, due to some inaccuracy and obvious mistakes 8 this translation can hardly be considered as reliable. The fragmentary English paraphrase of the missive given by Tadesse Tamrat is founded on its version preserved by alMufaḍḍal b. Abỉ'l-Faḍā’il. ${ }^{9}$

\section{Translation of al-Nuwayrīs Version of the Missive}

"The humblest Mamluk, Emir of the Amhara kisses the ground and prostrates before the Sultan al-Malik al-Zāhir, let God make his reign perpetual!

[I am writing that] that an envoy arrived from the governor of (the town) of Qūs ${ }^{10}$ and this is because of the monk who came to us, but a metropolitan didn't come to us. Our country is that of our Lord, the Sultan and we are his slaves. Let our Lord [the Sultan] issue the order to the Father Patriarch to ordain for us a metropolitan, a good and learned man, who is not greedy for gold and silver and to send him to the town of Aswan. Then the humblest Mamluk will deliver whichever is needed to the gates (functionaries ?) of al-Malik alMuzaffar, ruler of Yemen, and he, in his turn, will convey it to the gates of the Sultan.

8 As illustration are listed only some typical mistakes made by Mrs Tolmacheva. Cf. the

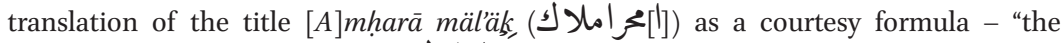
most respectable of the rulers" (محر|ملاكلك) as addressed to Baybars I. The expression was translated as "from some locality in Qūṣ" because the ون [جهة] understood as the conjunction wa- followed by the preposition ilâ. In fact, here the title wālì ("governor") should be read. The monk's remark that "they are not moving without companion" (ما ير وح [بغير] رفيق) was completely misunderstood: "Breath only with a friend". See: Арабские источники ХIII-XIV вв. по этнографии и истории Африки южнее Сахары [Arabic Sources of the 13th-14th centuries on the ethnography and history of Africa South of the Sahara], t. 4, transl. V.V. Matveyev, L.E. Kubbel, M.A. Tolmacheva in cooperation with N.A. Dobronravin (Памятники письменности Востока, CXVI [Written Sources of the Orient, vol. cxvi]), Moscow, 2002, pp. 390-391, 402-403.

9 Taddesse Tamrat, op. cit., pp. 126 (nn. 2, 3), 127 (nn. 1, 2).

10 The town in the central part of Egypt which from the Hellenistic epoch onwards became the starting point for roads linking the Nile valley and the ports on the Red sea (J-Cl. Garcin, "Qūṣ", in: The Coptic Encylopaedia, Ed. in chief Aziz S. Atiya, vol. 7, New York - Toronto - Oxford, 1991, p. 2043 (pp. 2043-2046)). 
As to the reason, why the envoys did arrive to the Sultan at such a late time: this was exclusively because of my stay in Bīkār (?). ${ }^{11}$ The King David passed away and his son ascended the throne.

Oh, my Lord, in my army I have a hundred thousand Muslim horsemen; as for the Christians, they are very numerous, almost countless. Moreover, all of them are your ghulams and obey your order. And the Great Metropolitan is crying and appealing to you and all these people say: "Verily, may God prolong the life of our Sultan, the Ruler of Egypt and destroy his enemies". And the people respond: "Let it be so!" And the humblest Mamluk protects all Muslims, who arrive in our country, and lets them go where they wish.

This is true that the envoy sent by the governor of Qūṣ contracted smallpox and is ill. As to our country, it is unhealthy, so that if anyone falls ill, nobody may enter to him, and everyone, who breathes his scent, will get sick and die. And the monk said: "They are not moving without companion..."

And as to us, we protect every Muslim who came. And give the order and send a metropolitan who will take his care of them.

It is completed".

Those who commented on this text paid most attention upon the request to send a new metropolitan and the fact that the hierarch could not be sent. ${ }^{12}$ Another observation was regarding the friendly relations between Yəkunno Amlak and "not only the local Muslims, but also the rulers of Yemen and Egypt". ${ }^{13}$ However, some interesting details regarding the author's attitude towards the Muslims escaped the scholars' attention. They are: his self-deprecation, his calling himself "the humblest Mamluk", proclaiming the Sultan Baybars I "his Lord" and calling the Ethiopian Christians "slaves and ghulams" of this ruler. Those statements expressed in writing are far beyond the limits of the usual formulas ${ }^{14}$ as required by the Oriental etiquette. Anyway, the subsequent Kings of Ethiopia avoided the use of such expressions in their correspondence with the rulers of Egypt and had never called the latter their sovereign.

The question, which should be asked here, is as follows: why the real founder of the "Solomonic" dynasty was ready to surrender to the Muslims and to transfer his subjects under their political control? An answer is given by all three survived versions of the missive. According to them already in AH 673 / AD 1274-75, i.e. four years after the commonly recognized date of the

\footnotetext{
$11 \quad$ Unidentified toponym.

12 Taddesse Tamrat, op. cit., p. 70.

13 Ibid., p. 126.

14 Taddesse Tamrat called them, probably as a result of an accidental slip of his pen, "the usual humble protestations" (Taddesse Tamrat, op. cit., p. 126) instead of prostrations.
} 
dynastic coup d'État, Yəkunno Amlak did not succeed in his attempts to subdue the whole Ethiopia, since he had to mention the enthronization of a son of a certain "King David": both the father and the son belonged to the Zagwe dynasty. In that situation he was in search of allies and protectors. Even the status of a Muslim governor over Christian Ethiopia in this situation might have seemed attractive to him. If Baybars I would have shown interest to such a proposal, it would be the first step towards the submission of Ethiopia to the Mamluk Sultanate and, who knows, the gradual eradication of Christianity in the Horn of Africa, which would have every chance to share the fate of Nubia, where any trace of Christian faith disappeared because of the apostasy of the local élite.

However, the Sultan al-Malik al-Ẓāhir didn't give a favourable answer to the petition from one of the rulers of such a remote country as Ethiopia to him. Possibly his advisers from among the Copts dissuaded him from any serious contact with a rebel, who was trying to overthrow the Zagwe dynasty, which was considered at that period as legitimate. In his official answer, Baybars addressed his Ethiopian correspondent as an equal to himself using the titles hașe "emperor", ${ }^{15}$ malik Amhara "King of the Amhara", akbar mulūkal-Hubshān "the greatest King of the Ethiopians", etc. ${ }^{16}$ Thus the Sultan completely rejected, albeit in a very polite manner, the attempt of Yəkunno Amlak to surrender to his supreme power and to become in perspective his governor over Ethiopia.

15 In its Old Amharic form transcribed as حطى.

16 al-Nuwayrī, op. cit., p. 136; Moufazzal ibn̈ Abil-Fazail, op. cit., p. 385 . 